\title{
Occurrence of the sexual morph of Erysiphe macleayae on Chelidonium majus in Romania
}

\author{
Vasilică-Claudiu Chinan * \\ Alexandru Ioan Cuza University, Faculty of Biology, Bd. Carol I, No. 20A, 700505, Iaşi, Romania
}

\begin{abstract}
The sexual morph (chasmothecium) of Erysiphe macleayae on Chelidonium majus has been found in Romania for the first time. Although the asexual morph of this powdery mildew on C. majus is known from many countries, the occurrence of chasmothecia on this host is rather rare. A description of morphological characters and an analysis of the phylogenetic relationship of ITS sequences of the Romanian specimens are presented.
\end{abstract}

Key words: greater celandine, powdery mildew, chasmothecia, ITS

\section{Introduction}

Erysiphe macleayae was originally described from China as a parasite of Macleaya cordata (Willd.) R. Br. and $\mathrm{Pa}$ paver nudicaule L. (Zheng and Chen 1981). Besides these hosts, it was also reported as causal agent of powdery mildew on Macleaya microcarpa (Maxim.) Fedde (Park et al. 2012), Meconopsis cambrica (L.) Vig. (Schmidt and Scholler 2011, Braun and Cook 2012), and Chelidonium majus L. (Jiang et al. 2015), all of them plant species of the family Papaveraceae. Outside this family, it was recently found on Torenia fournieri Linden ex E. Fourn. (Men et al. 2014), a species of Linderniaceae.

In the last decade, the powdery mildew of Chelidonium majus (greater celandine) has been a disputed topic in the context of the extension of its range of distribution and the absence, until recently, of the sexual morph. The first report of this disease based on DNA analysis of the anamorph was published by Jankovics (2007) from Hungary, who identified the powdery mildew on C. majus as Oidium neolycopersici. In a study of the powdery mildews of Papaveraceae species in Germany, Schmidt and Scholler (2011) mentioned that the powdery mildew of $C$. majus may be related to or even conspecific with E. macleayae. Later, Pastirčáková and Pastirčák (2013) confirmed on the basis of morphological characteristics that the anamorph of the $C$. majus powdery mildew in the Czech Republic and Slovakia is caused by a Pseudoidium species. Finally, Jiang et al. (2015) published the first collection of the chasmothecia on C. majus in China and identified the causal agent as Erysiphe macleayae. Fruiting bodies (chasmo- thecia) were also found in Germany in 2014 (Braun 2014) and Slovakia in 2014 and 2015 (Pastirčáková et al. 2016). Recently, the anamorph of E. macleayae on C. majus was also reported from Ukraine (Heluta and Kravchuk 2015).

Based on a collection from Moldavia (Romania), the anamorph of this powdery mildew on C. majus was described by Iacob and Drobotă (2008) as a new species, Oidium chelidonii Iacob. Because of the absence of both a Latin diagnosis and a holotype, this name is invalid (Pastirčáková et al. 2016).

The aim of this paper is to report the new occurrence of the teleomorph of E. macleayae on C. majus, which is new for Romania. Furthermore, a description of the Romanian specimens and a phylogeny inferred including the newly obtained ITS sequences are provided.

\section{Materials and methods}

Leaves of Chelidonium majus infected with powdery mildew were collected from the urban area of Iași, Romania. For light microscopic examination, fresh samples were mounted in $2 \% \mathrm{KOH}$. The sexual and asexual features (chasmothecia, asci, ascospores, conidia, and conidiophores) were described, measured, and photographed. The given size ranges of all structures are based on 30 measurements. Statistical data (length and width) are given as arithmetic mean \pm standard deviation (SD). For the examination of the conidial germination, the moist chamber method with saturated aqueous solution of potassium sulphate as described in Braun and

\footnotetext{
* Corresponding author, e-mail: vasilechinan@yahoo.com
} 
Cook (2012) was used. The analyzed specimens are deposited in the Herbarium of Alexandru Ioan Cuza University of Iasi, Romania (Index Herbariorum abbreviation: I).

For the molecular characterization, DNA was extracted from the chasmothecia (voucher specimen I 183221) and the anamorph (voucher specimen I 183222). The nuclear ribosomal internal transcribed spacer (ITS) region was amplified using primers ITS1F 5'-CTTGGTCATTTAGAGGAAGTAA-3' (Gardes and Bruns 1993) and ITS4, 5'-TCCTCCGCTTATTGATATGC-3' (White et al. 1990) and sequenced at Alvalab (Santander, Spain). The newly obtained sequences were deposited in GenBank (accession numbers KU756266 and KU756267). For the phylogenetic analysis, sequences of the powdery mildew specimens isolated from Chelidonium majus (Jankovics 2007, Jiang et al. 2015, Kovács et al. 2011, Pastirčáková et al. 2016, Takamatsu et al. 2015), Macleaya cordata (Jiang et al. 2015, Pastirčáková et al. 2016, Takamatsu et al. 2015), Macleaya microcarpa (Park et al. 2012), and Torenia fournieri (Men et al. 2014) were downloaded from GenBank and aligned with the ClusatlW algorithm (Larkin et al. 2007). Sequences of Erysiphe aquilegiae DC., E. magnoliae (Sawada) U. Braun \& S. Takam. from Takamatsu et al. (2015), and E. deutziae (Bunkina) U. Braun \& S. Takam. from Denton and Henricot (2007) were used as outgroup taxa as these species were recovered as basal to the E. aquilegiae clade in the comprehensive phylogenetic analysis of Takamatsu et al. (2015). A list of all the 35 sequences used in the analysis is included in the On-line Suppl. Tab. 1. Maximum likelihood (ML) analysis was used as a tree building method. The K2 (Kimura 2-parameter) model of nucleotide substitution was selected using BIC (Bayesian Information Criterion). The reliability of phylogenetic relationships was evaluated using a non-parametric bootstrap analysis with 1000 replicates and ML bootstrap values (BP) are presented at branch nodes. The bootstrap values exceeding 75 were considered well supported. All computations were performed using MEGA v6.0.5 (Tamura et al. 2013).

\section{Results and discussion}

In the autumn of 2014, several specimens of $C$. majus with powdery mildew were collected in Iasi, Romania, including a single leaf with a few young chasmothecia. A year later, alongside a building wall near the headquarters of the Alexandru Ioan Cuza University of Iași, a powdery mildew specimen on C. majus with mature chasmothecia on basal leaves was found. Of the 12 leaves of the plant, nine showed disease symptoms. Besides this, although other specimens of greater celandine with powdery mildew were investigated, only a single additional leaf with chasmothecia on another specimen was found. The collected specimens belong to $E$. macleayae. The occurrence of the teleomorph of this powdery mildew is new for Romania.

Erysiphe macleayae R.Y. Zheng \& G.Q. Chen, Sydowia 34: 290 (1981)

Mycelium white, amphigenous, but mostly epiphyllous, covering the entire surface of the older basal leaves, or form- ing patches mainly on the upper lobes of the leaf (Fig. 1A). Hyphae 4-6 $\mu \mathrm{m}$ wide, with lobed or nipple-shaped appressoria. Conidiophores straight or slightly curved, hyaline, $70-135$ (mean $99.8 \pm 14.7) \times 8-12 \mu \mathrm{m}$ (mean $10.0 \pm 0.9$ ), foot-cells cylindrical, followed by 1-2 shorter cells. Conidia formed singly, ellipsoid, doliiform-cylindrical, hyaline, 25$50($ mean $38.7 \pm 5.4) \times 10-20 \mu$ m (mean $14.6 \pm 2.7)$. Germ tubes formed subapically (Pseudoidium type) (Fig. 1D). Chasmothecia scattered to gregarious, subglobose, 75-116 $\mu \mathrm{m}$ (mean $92.3 \pm 10.2$ ) in diameter, initially light brown, then dark brown. Appendages 15-25 per chasmothecium, simple, often tortuous-sinuous, up to $700 \mu \mathrm{m}$ long, light brown (Fig. 1B). Asci 3-6 per chasmothecium, 45-70 (mean $57.1 \pm 7.6) \times$ 30-55 $\mu \mathrm{m}$ (mean 37.4 \pm 7.9 ), obovoid-saccate, short-stalked, 3-6-spored. Ascospores 16-26 (mean 21.6 \pm 2.7$) \times 10-13$ $\mu \mathrm{m}$ (mean $10.7 \pm 0.8$ ), ellipsoid-ovoid (Fig. 1C).

Specimens examined: on living leaves of Chelidonium majus, ROMANIA, Iasi, Anastasie Fătu Botanic Garden, Dumbrava Roşie Street, 7 Oct. 2014, leg. et det. V. Chinan, voucher specimen I 183224 (anamorph and immature chasmothecia); Iasi, Pinului Street, near the Alexandru Ioan $\mathrm{Cu}$ za University, 10 Oct. 2015, leg. et det. V. Chinan, voucher specimens: I 183221(teleomorph, GenBank accession number KU756266), I 183222 (anamorph, GenBank accession number KU756267); 20 Oct. 2015, leg. et det. V. Chinan, voucher specimen I 183223 (teleomorph).

Phylogenetic analysis: the sequences obtained from the chasmothecia (KU756266) and the anamorph (KU756267) of the Romanian specimens are identical, and positioned well with the other sequences of Erysiphe macleayae parasitizing C. majus, M. cordata, M microcarpa and T. fournieri
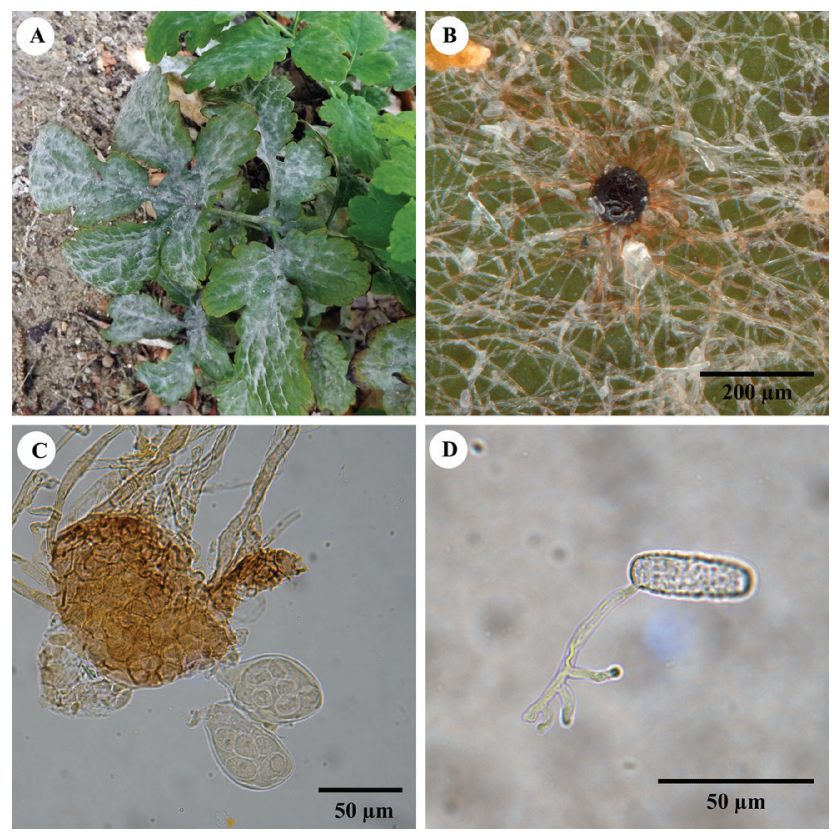

Fig. 1. Erysiphe macleayae: A - symptoms on Chelidonium majus, B - chasmothecium, conidia and mycelium on the leaf surface, C - crushed mature chasmothecium, asci with ascospores, D germinated conidium. 
$(\mathrm{BP}=96)$ (Fig. 2). These results confirm the species identity and the conspecificity of the asexual and sexual morphs found on C. majus in Romania. The intraspecific molecular variability of $E$. macleayae is very low: specimens of diverse geographical origins differ at most in two substitutions (0$0.4 \%$ uncorrected pairwise distance).

Both the sexual and the asexual morph of the Romanian collections agree well morphologically with the descriptions of E. macleayae from M. cordata (Zheng and Chen 1981) and C. majus (Jiang et al. 2015, Pastirčáková et al. 2016).

It is noteworthy that in Europe chasmothecia of E. macleayae on C. majus were found in autumn 2014, simultaneously in Germany (Braun 2014), Slovakia (Pastirčáková et al. 2016) and Romania (in this study). In these countries, the anamorph on this host was first found in 2003 (Jage et al. 2010), 2006 (Pastirčáková and Pastirčák 2013), and 2007 (Iacob and Drobotă 2008) respectively. This confirms that ma- ny powdery mildew fungi do not produce chasmothecia for several years after extending their geographical areas or host ranges (Kiss 2002, Kiss et al. 2002). The annual monitoring of this powdery mildew made in Slovakia by Pastirčáková et al. (2016), in the period 2006-2015 fully supports this observation. Furthermore, homo- or heterothallism of the species concerned may play an important role. Heterothallic species often need more time to find compatible thalli to be able to reproduce sexually. The individual life cycle of E. macleay$a e$ is still unknown, but heterothallism appears to prevail among powdery mildews (Wolfenbarger et al. 2015).

\section{Acknowledgments}

I would like to thank Lucian Fusu for all of the help with the phylogenetic analysis and the anonymous reviewers, whose comments and suggestions helped improve this manuscript.

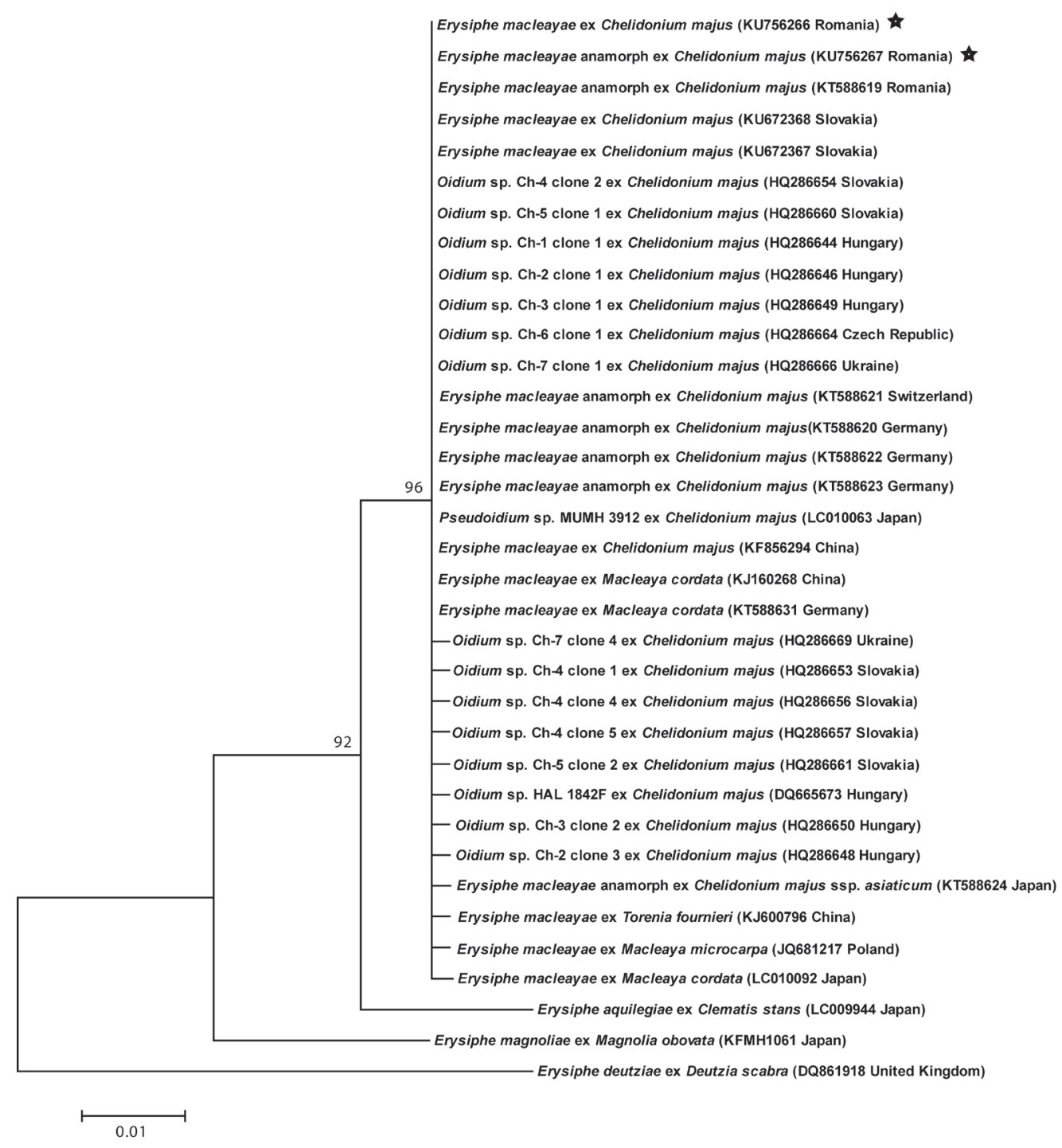

Fig. 2. Rooted maximum likelihood tree based on ITS sequences. The sequences of Erysiphe macleayae from Romania obtained in this work are indicated by a star. Bootstrap support values from 1000 pseudoreplicates are reported above nodes. 


\section{References}

Braun, U., 2014: Fungi selecti exsiccati ex Herbario Universitatis Halensis - nos. 211-220. Schlechtendalia 28, 35-37.

Braun, U., Cook R. T. A., 2012: Taxonomic manual of the Erysiphales (powdery mildews). CBS Biodiversity series 11. CBSKNAW Fungal Biodiversity Centre, Utrecht, The Netherlands.

Denton, G., Henricot, B., 2007: First report of powdery mildew on Deutzia spp. in the UK. Plant Pathology 56, 353-353.

Gardes, M., Bruns. T. D., 1993: ITS primers with enhanced specificity for basidiomycetes - application to the identification of mycorrhizae and rusts. Molecular Ecology 2, 113-118.

Heluta, V. P., Kravchuk, H. A., 2015: First records of a new invasive fungus, Erysiphe macleayae (Erysiphales), in Ukraine. Ukrainian Botanical Journal 72, 39-45.

Iacob, V., Drobotă, I., 2008: New parasitic and saprophytic micromycetes on cultivated horticultural plants from Moldavia. Lucrări științifice, Seria Horticultură 51, 1049-1054.

Jage, H., Klenke, F., Kummer, V., 2010: New records and remarkable confirmations of phytoparasitic microfungi in Germany - Erysiphales (Powdery mildews). Schlechtendalia 21, 1-140.

Jankovics, T., 2007: First report of powdery mildew (Oidium sp.) on greater celandine (Chelidonium majus). Plant Pathology 56, 353-353.

Jiang, W., Liu, S., An, B., Wanga, L., Li, Y., Takamatsu, S., Braun, U., 2015: Chasmothecia of Erysiphe macleayae on Chelidonium majus confirm species identification. Mycoscience 56, $132-135$.

Kiss, L., 2002: Advances in the identification of emerging powdery mildew fungi using morphological and molecular data. Acta Microbiologica et Immunologica Hungarica 49, 245-248.

Kiss, L., Bolay, A., Takamatsu, S., Cook, R. T. A., Limkaisang, S., Ale-Agha, N., Szentivanyi, O., Boal, R. J., Jeffries, P., 2002: Spread of the North American snowberry powdery mildew fungus, Erysiphe symphoricarpi (syn. Microsphaera symphoricarpi), to Europe. Mycological Research 106, 1086-1092.

Kovács, G. M., Jankovics T., Kiss L., 2011: Variation in the nrDNA ITS sequences of some powdery mildew species: do routine molecular identification procedures hide valuable information? European Journal of Plant Pathology 131, 135-141.
Larkin, M. A., Blackshields, G., Brown, N. P., Chenna R., Mcgettigan, P. A., McWilliam, H., Valentin, F., Wallace, I. M., Wilm, A., Lopez, R., Thompson, J. D., Gibson, T. J., Higgins, D. G., 2007: Clustal W and Clustal X version 2.0. Bioinformatics 23, 2947-2948.

Men, X.-Y., Liu, S.-Y., Jiang, W.-T., Li, Y., 2014: First Report of Powdery Mildew Caused by Erysiphe macleayae on Torenia fournieri in China. Plant Disease 98, 1277-1277.

Pastirčáková K., Pastirčák, M., 2013: A powdery mildew (Pseudoidium sp.) found on Chelidonium majus in the Czech Republic and Slovakia. Czech Mycology 65, 125-132.

Pastirčáková, K., Jankovics, T., Komáromi, J., Pintye, A., Pastirčák, M., 2016: Genetic diversity and host range of powdery mildews on Papaveraceae. Mycological Progress 15: 36.

Park, M. J., Cho, S. E., Piątek, M., Shin, H. D., 2012: First report of powdery mildew caused by Erysiphe macleayae on Macleaya microcarpa in Poland. Plant Disease 96, 1376-1376.

Schmidt, A., Scholler, M., 2011: Studies in Erysiphales anamorphs (4): species on Hydrangeaceae and Papaveraceae. Mycotaxon $115,287-301$.

Takamatsu, S., Ito Arakawa, H., Shiroya, Y., Kiss, L., Heluta, V., 2015. First comprehensive phylogenetic analysis of the genus Erysiphe (Erysiphales, Erysiphaceae) I. The Microsphaera lineage. Mycologia 107, 475-489.

Tamura, K., Stecher, G., Peterson, D., Filipski, A., Kumar, S., 2013: MEGA6: molecular evolutionary genetics analysis version 6.0. Molecular Biology and Evolution 30, 2725-2729.

White, T. J., Bruns, T., Lee, S., Taylor, J. W., 1990: Amplification and direct sequencing of fungal ribosomal RNA genes for phylogenetics. In: Innis, M. A. et al. (eds.), PCR protocols: a guide to methods and applications, 315-322. Academic Press Inc., New York.

Wolfenbarger, S. N., Twomey, M. C., Gadoury, D. M., Knaus, B. J., Grünwald, N.J., Gent, D. H., 2015: Identification and distribution of mating-type idiomorphs in populations of Podosphaera macularis and development of chasmothecia of the fungus. Plant Pathology, 64, 1094-1102.

Zheng, R. Y., Chen, G. Q., 1981: The genus Erysiphe in China. Sydowia 34, 214-327. 